\title{
Tanenlerin Kanatlı Hayvan Beslemede Etkileri
}

\author{
Süleyman ÇALIŞLAR iD \\ Kahramanmaraş Sütçü İmam Üniversitesi, Ziraat Fakültesi, Zootekni Bölümü Kahramanmaraş \\ $\triangle$ : scalislar@ksu.edu.tr
}

\section{ÖZET}

Tahıl, baklagil, sebze ve meyvelerde bulunan en önemli ikincil metabolitlerden birisi de tanenlerdir. Tanenler, azot içermeyen, hidrolize ve kondense şekillerde olan, amorf yapıdaki polimerik fenolik bileşiklerdir. Hidrolize olabilen tanenler bitkilerde daha az miktarlarda bulunurlar. Kondense tanenler ise, hidroliz ile parçalanmaya dayanıklı flavonoid ünitelerinden meydana gelmiştir. Tanenler, antioksidan, antikanserojen, antimikrobiyal ve antiparaziter fonksiyonlara sahiptirler. Diğer yandan anti besinsel özellikleri nedeniyle kanatlı hayvanlar üzerinde bazı olumsuz etkileri vardır. Ruminantlarla karşılaştırıldığında kanatlı hayvanlar, tanenlere karşı daha hassastırlar. Yüksek miktardaki tanenler, kanatlı hayvanlarda iştahın azalması ve buna bağlı olarak yem tüketiminin düşmesi, besin emiliminin kötüleşmesi vb. gibi performans kayıplarına yol açarlar. Ayrıca güçlü bir karaciğer ve böbrek zehiri olarak da bilinen tanenler, kanatlı hayvanların yemek borusunda tahrişe, kursak, taşlık ve duedonumda nekrozlara, kemik bozukluklarına ve dokularda çeşitli düzeyde patolojik değişimlerin meydana gelmesine neden olurlar.

$\mathrm{Bu}$ derlemede, tanenin özellikleri, sinfflandırılması, kanatlı hayvanlarının beslenmesindeki genel etkileri ve tanen miktarını azaltan uygulamalar incelenmiştir.

\section{Effects of Tannins on Poultry Nutrition}

One of the most important secondary metabolite found in cereals, legumes, vegetables and fruits is tannins. Tannins are polymeric phenolic compounds in the amorphous structure which are nitrogenfree, hydrolyzed and condensed forms. Tannins that can be hydrolyzed are found in smaller amounts in plants. Condensed tannins have flavonoid units resistant to hydrolysis.

Tannins have antioxidant, anticarcinogenic, antimicrobial and antiparasitic functions. On the other hand, due to their antinutritional contents, they have some negative effects on poultry. According to ruminants, poultry are more sensitive to tannins. High amounts of tannins lead to performance losses in poultry, such as reduced appetite, reduced feed intake, and poor absorption of nutrients etc. Tannins, also known as potent liver and kidney poisons, cause poultry to develop bone disorders and pathological changes at various levels in tissues, irritation in esophagus, necrosis in crop, gizzard, and duodenum.

In this review, the characteristics of tannins, their classification, the general effects of tannins on feeding of poultry and practices that reduce the amount of tannins have been examined.
\end{abstract}

DOI:10.18016/ ksudobil.359982

\section{Makale Tarihçesi}

Geliş Tarihi : 01.12.2017

Kabul tarihi : 15.01.2018

\section{Anahtar Kelimeler}

Tanen,

Fenolik bileşik,

kanatlı besleme

\section{Derleme Makale}

\section{Article History}

Received : 01.12.2017

Accepted : 15.01.2018

\author{
Keywords \\ Tannin, \\ Phenolic compound, \\ Poultry nutrition
}

\section{Review Article}

To cite : Çalışlar S 2018. Tanenlerin Kanatlı Hayvan Beslemede Etkileri. KSÜ Tarım ve Doğa Derg 21(4): 615-623, 2018. DOI:10.18016/ ksudobil.359982

\section{GİİS}

Tanenlerin fizyolojik etkilerine, fayda veya zararlarına (toksitite) ilişkin çeşitli bilgiler mevcuttur. Yapılan araştırmalarda, tanenlerin, antioksidan (McCune ve Johns, 2002; Yilmaz ve Toledo, 2004) antikanserojen (Goun ve ark., 2002) antibakteriyel (Akiyama ve ark., 
2001; Funatogawa, 2004), antiviral (Lin ve ark., 2004), iltihaplanmayı önleyici (Kaur ve ark., 2004) ve antiparaziter (Kolodziej ve Kiderlen, 2005) etkilere sahip oldukları belirtilmiştir.

Tahıl taneleri, baklagil tohumları, kestane, meşe palamudu, sumak, sorgum gibi bitkilerde fazla miktarda bulunan tanenler, besinsel etkilerin yanında antibesinsel etkiler de gösterirler (Khanbabaee ve Ree, 2001; Ağma Okur, 2010). Tohuma göre tohum kabuğu 10 kat daha fazla tanen içerir (Yalçın, 2013). Buruk ve acı bir tada sahip olan tanenler, tohumun ve neslin muhafazasını sağlar (Aktaş ve Akkan, 2011).

Tanenler yüksek sayıda- serbest hidroksil grubu içerdiklerinden proteinlere, karbonhidratlara (Olomu, 1995; Hagerman, 2002; Goel ve ark., 2005) kalsiyum, fosfor, magnezyum ve B12 vitaminine bağlanmak suretiyle (Silanikove ve ark.,2001; Min ve ark., 2013) besinlerden yararlanmayı azaltirlar (Arigator ve Samman, 1994; Aydın ve Üstün, 2007; Yalçın, 2013).

Kanatlı hayvanlar, ruminantlara göre tanene karşı daha hassastırlar (Yalçın, 2013). Yüksek oranda tanen içeren yemler ile beslenen kanatlı hayvanlarda, yem tüketiminde azalma, gelişmede gerileme, yemden yararlanmada kötüleşme, canlı ağırlıkta azalma gibi verim kayıpları meydana gelmektedir (Reyes Sanchez ve ark., 2000; Kumar ve ark., 2007). Güçlü bir karaciğer ve böbrek zehiri olarak da bilinen tanenlerin yüksek miktarları, kanatlı hayvanların akciğer, karaciğer, kalp, ince bağırsak ve pankreas dokularında patolojik değişikliklere neden olurlar (Ortiz ve ark., 1994). Tanenlerin irritan etkisine (Reed, 1995) bağlı olarak kanatlı hayvanların yemek borusunda tahriş, kursak, proventrikulus ve duedonumda ise nekrozlar oluşmaktadır (Nyachoti ve ark., 1997). Tanen miktarına bağlı olarak etlik piliçlerin bacak kemiklerinde dışa doğru eğilme, eklemlerde şişmeler ve ayakta durmada zorlanma davranışları meydana gelmektedir (Yalçın, 2013).

$\mathrm{Bu}$ derlemede, tanenlerin temel özellikleri ve kanatlı hayvan beslenmesindeki genel etkileri incelenmiştir.

\section{Tanenlerin Yapısı, Sınıflandırılması ve Etki Şekli}

Tanenlerin biyosentezi, yapısı, sinıflandırılması, fonksiyonu ve hayvan beslenmesindeki etkilerine ilişkin çeşitli araştırmalar yapılmıştır. Deri ve boya endüstrisinde yaygın olarak kullanılmasina (Gnanamani ve ark., 2001; Aydın ve Üstün, 2007) bağlı olarak tanen terimi ilk kez hayvan derilerini tabaklamada ortaya çıkmıştır.

Tanenler, molekül ağırlığı 500 ile 20.000 dalton arasında değişen bileşiklerdir. Protein, amino asit, alkaloid gibi çeşitli organik bileşiklere bağlanabilen, çökeltici, büzüştürücü etkiye sahip olan ve azot içermeyen tanenler; polifenolik biyomoleküllerdir (Zivkovic ve ark., 2009). Suda kolloidal çözelti oluşturan, kristal yapıda olmayan renksiz bileşiklerdir (Martin ve Michael, 1983).

Tanenler; galo, elajik, kompleks ve kondense olmak üzere dört ana gruba ayrılırlar. Galloil üniteleri veya bunların türevlerinin; şeker, kateşin veya triterpenoid ünitelerine bağlanmasıyla "galo tanenler" oluşur. "Elajik tanenler", kateşin ünitesi içermezler ve en az iki galoil ünitesi C-C bağı ile birbirine bağlanmış durumdadır. Kateşin ünitelerinin glikozidik bağ ile galo tanenlere ya da elajik tanenlere bağlanmak suretiyle "kompleks tanenler" meydana gelir (Lewis ve Yamamoto, 1989). "Kondense tanenler" (proantosiyanidin) ise kateşin ünitelerinin 4., 6. veya 8. karbonlar üzerinden birbirlerine bağlanmasıyla oluşmuştur. Hidrolize olabilir tanen (HT) molekülünün ortasında bulunan bir adet karbonhidratın (D-glukoz) hidroksilleri zaylf asit ve zayif bazlar tarafindan kismen veya tamamen hidrolize edilerek fenolik gruplar (galik asit vb) üretilir (Khanbabaee ve Ree, 2001; Ashok ve Upadhyaya, 2012). Tanen, tannenaz enzimi vasitasiyla hidrolize edilir ve hidrolize tanenler toksik bileşiklerden \%20 daha fazla zehir etkisine sahiptirler (Reed, 1995). Kondense tanenlere göre hidrolize olabilir tanenler bitkilerde daha az miktarlarda bulunurlar (Hassanpour ve ark., 2011).

Tanenler, sindirim sisteminde yıkımlanmak suretiyle toksisitesi daha fazla olan galik asit, pirogallol ve pirokateşol gibi fenolik yapılara dönüşürler. Bu fenolik yapılar sindirim sisteminden daha hızlı absorbe edilirler (Schofield ve ark., 2001). Tanene göre, tanenin hidrolizinden meydana gelen galik asit 1.5 kat, pirogalol ise 5 kat daha zehirlidir (Şener ve Yıldırım, 2000).

Birçok bitki çeşidinde yaygın olarak bulunan tanenler, sanki bir ilaçmış gibi bitkileri böceklere karşı korur ve onların büyümelerinin düzenlenmesinde rol oynarlar (Katie ve ark., 2006).

Tanenler etkilerini değişik şekillerde gösterirler. Tükürük salgisındaki proteinler ile bileşik yapan tanenler büzüştürücü etki yapmak suretiyle tükürüğün kayganlaştırıcı etkisini azaltırlar (Gawel, 1998). Tanenler, kanatl hayvanların sindirim sisteminde görev yapan birçok enzimi engellemek suretiyle geniş yelpazeli bir etki meydana getirirler (Longstaff ve McNab, 1991).

Tanenler, buruk ve acı tat nedeniyle kanatl hayvanlarda iştahın azalmasına, yem tüketiminin düşmesine (Kumar ve ark., 2005), besinlerin sindirim ve emiliminin kötüleşmesi gibi enerji ve mineral metabolizması üzerinde çeşitli antibesinsel olumsuzluklara yol açarlar (Atteh, 2002; Ebadi ve ark., 2005). Tanenin yüksek miktarları, mide ve bağırsak yangısına neden olabilmektedir (Aydın ve Üstün, 2007). 
Kanatlı hayvanların beslenmesinde yaygin olarak kullanılan tahıllarda ve baklagillerde bulunan tanenler, proteinlerden yararlanmayı azaltmakta ve büyümeyi geriletmektedir (Kaya ve Yavuz, 1993). Ayrıca sindirim sistemindeki epitel hücresi zarlarının dış yüzeyindeki mukoid salgıdaki proteinlerin çöktürülmesi sonucu kalsiyum, fosfor, magnezyum, sodyum, potasyum demir ve kobalt gibi mineraller ile glikoz ve metiyonin emilimi engellenmektedir (Hassan ve ark., 2003). Besinlerden yararlanmanın olumsuz etkilemesine, tanenin pankreatik tripsin ve amilaz aktivitesinde meydana getirdiği azalmanın etkisi olduğu sanılmaktadır (Silanikove ve ark., 1994).

Hidrolize edilebilir tanenler (HT) zayıf asit, zayıf baz, sıcak su, bakteri, maya, mantar ve enzimler (esteraz vb) tarafından parçalanabilirler (Kuloğlu, 2007). HT'nin sindirim kanalından emilmesi ile birlikte zehirli etkiler ortaya çıkar (Yalçın, 2013). Çözünebilir tanene en iyi örnek tanik asittir. Bu asit enzimatik olarak ya da kendiliğinden glikoz ve galik asite ayrışmaktadır. Bu gruba ait diğer tanenler hidrolize olduklarında ise galik asit yerine elajik asit oluşmaktadır (Hagerman, 2002; Edwin-Jarald, 2007; Bele ve ark., 2009).

Kondense tanenler (KT), suda çözünmüş olarak çok az miktarda bulunurlar ve büyük bir kısmı ise suda çözünmezler (Ashok ve Upadhyaya, 2012). Yemlerde serbest halde bulunan KT, sindirim kanalında selüloz ve protein gibi yapılarla bağlandıklarından emilerek kana geçemezler. Bundan dolayı KT'nin karaciğer, dalak ve böbrek gibi hayati organlarda meydana getirdiği hasar, HT’ye göre daha düşük olmaktadır (Makkar, 2003). HT ise daha az salgilamaya neden olmak suretiyle iştahın azalmasına ya da aşırı salgılama yaptırarak mide-bağırsak yangılarına neden olmaktadır (Üstün ve Aydın, 2007).

\section{Tanenlerin Kanatlı Hayvanlar Üzerindeki Genel Etkileri}

KT genellikle meyveler, otlar, tahıllar ve baklagillerde ağırlıklı olarak bulunur. Çeşide göre değişmekle birlikte bitkiler, kuru ağırlığının \%5 ile \%50'si kadar tanen içermektedir. Tanenler çift çenekli bitkilerde ve özellikle baklagillerde çok fazla bulunurlar. Tahıllar ve baklagillerdeki tanen miktarı \%2 ile \%4, kırmızı sorgum çeşitlerinde ise $\% 6$ ile $\% 8$ arasında değişmektedir (Doka ve ark., 2004). Yemlerdeki tanen miktarı ise \%0 ile \%5.7 arasında değişmektedir (Akar ve ark., 1994). Yüksek miktardaki tanen, tavukların performansinı olumsuz etkilemekte (Hassan ve ark., 2003; Medugu ve ark, 2012) ve muhtelif sağlık sorunlarına yol açabilmektedir (Tablo 1). Kanatlı hayvanların tolere edebileceği tanen düzeyi ile ilgili değişik veriler mevcuttur. $\% 0.75$ ve $\% 1.5$ arasında tanen içeren yem ile beslenen genç piliçlerin canlı ağırlığında sırasıyla \%16 ve \%41 oranında azalma meydana gelmiştir (Kubena ve ark., 2001). \%0.5 ile \%2 arasındaki tanen miktarının ise tavukların yumurta verimini azalttığı (Martin-Tanguy ve ark., 1977), iştahı baskılamak suretiyle civcivlerin büyüme performansını gerilettiği bildirilmiştir (Ebrahim ve ark., 2015). \%5 ve üzerindeki tanen miktarları kanatlı hayvanlarda ölümlere neden olmuştur (Kaya ve Yavuz, 1993; Akar ve ark., 1994; Yavuz ve ark., 1997).

Yüksek miktardaki tanen yemlerin tadını acılaştırdığından, kanatlı hayvanların yem tüketimi olumsuz etkilenmekte (Kumar ve ark., 2005) buna bağlı olarak canlı ağırlık azalmakta ve yemden yararlanmada kötüleşme meydana gelmektedir (Reyes Sanchez ve ark., 2000).

Tanen içeriği $16 \mathrm{~g} / \mathrm{kg}$ olan kırmızı sorgumun etlik piliçlerde $\mathrm{N}, \mathrm{Ca}$, ve $\mathrm{P}$ tutulumuna etkisi olmamakla birlikte, $23 \mathrm{~g} / \mathrm{kg}$ tanen içeren rasyonlarla beslenen aynı etlik piliçlerin karaciğer ve böbrek yapılarında orta düzeyde histopatolojik bulgular gözlenmiştir (Kumar ve ark., 2007). Tanenler, besinlerin sindirimini negatif etkilemek suretiyle tavukların büyümesinde, yemden yararlanmasında ve yumurta veriminde düşüşe neden olmuşlardır (Marquardt, 1989). Tanen içeriğindeki artışa $(0,5,15,20$ ve $25 \mathrm{~g} / \mathrm{kg}$ yem $)$ bağlı olarak etlik piliçlerin yem tüketimi ve canlı ağırlık kazancında azalma meydana gelmiştir. $20 \mathrm{~g} / \mathrm{kg}$ tanen içeren rasyon piliçlerin enerji, protein, arjinin ve lösin'in sindirilebilirliğini, $25 \mathrm{~g} / \mathrm{kg}$ tanen içeren rasyon ise metiyonin ve fenilalaninin sindirilebilirliğini olumsuz etkilemiştir. Yüksek tanen düzeyine bağlı olarak fosforun sindiriminde iyileşme olmuştur (Iji ve ark., 2004). Yüksek miktarda tüketilen tanen, kanatlı hayvanlarda nişastanın sindirilebilirliğini olumsuz etkilemiştir (Flores ve ark., 1994; Mahmood ve ark., 2006; Selle ve ark., 2010).

Tanen içeriği \%1 olan yemle beslemede tavukların yem tüketimi, yumurta verimi ve yemden yararlanma oranlarında önemli bir fark oluşmadiğ 1 ancak tanen içeriği $\% 2$ ve $\% 4$ arasındaki yemlerin ise tavukların yem tüketimi, yumurta verimi ve yemden yararlanmasında bir azalma meydana getirdiği görülmüştür (Gualtieri ve Rappaccini, 1990; Kaya ve Yavuz, 1993; Akar ve ark., 1994; Yavuz ve ark., 1997). Rasyondaki tanen miktarının \%1'den fazla olması durumunda, tavukların yumurta veriminde düşüş ve yumurta sarısının dış kısmında yeşil renk meydana gelmiştir (Nyachoti ve ark., 1997; Yalçın, 2013). \%1.3 KT içeren yemlerin etlik piliçlerin yem tüketimine etkisinin önemsiz olduğu belirtilmiştir (Musharaf ve Latshaw, 1991).

KT metiyonin ve sistinin emilimini azaltmak suretiyle hayvanı toksik bileşiklere ve zehirlenmelere karşı daha duyarlı hale getirmektedir (Reed, 1995). Bundan dolayı yüksek miktarlardaki tanenin hidrolizi sonucu açığa çıkan galik asidin 4-0- metil galik aside dönüştürülerek etkisiz hale getirilebilmesi için kolin ve metiyonin gibi metil vericilerine ihtiyaç olduğundan rasyonlara metiyonin ve kolin ilavesinin yapılması ile 
tanenden kaynaklanan problemler minimize edilmektedir (Atteh, 2002).

Tablo 1. Tanenlerin etlik piliçler üzerine etkileri

\begin{tabular}{|c|c|c|c|c|c|}
\hline Kaynak & $\begin{array}{l}\text { Tanen } \\
\text { çeşidi }\end{array}$ & Hayvan & $\begin{array}{c}\text { Uygulama } \\
\text { oranı, \% }\end{array}$ & Etki & Kaynak \\
\hline Tanik asit & $\mathrm{HT}$ & $\begin{array}{l}\text { Etlik piliç } \\
\quad(1-35 \\
\text { gün) }\end{array}$ & 0.50 & $\begin{array}{l}\text { Büyüme performansında ve kan } \\
\text { glikoz düzeyinde azalma, kalça ve } \\
\text { gögüs eti yağ içeriğinde artış, } \\
\text { karaciğer kolesterol oranında azalma } \\
\text { meydana gelmiştir }\end{array}$ & $\begin{array}{c}\text { Starcević ve ark., } \\
2015\end{array}$ \\
\hline Tanik asit & $\mathrm{HT}$ & $\begin{array}{l}\text { Etlik piliç } \\
\quad(1-12 \\
\text { gün) }\end{array}$ & 1.0 & $\begin{array}{l}\text { Yem tüketiminde ve ağırlık } \\
\text { kazancında azalma; tekli doymamış } \\
\text { yağ asitlerini azaltarak sıcaklık stresi } \\
\text { altındaki piliçlerin göğüs kası yağ } \\
\text { asitleri profilinde iyileşme olmuştur }\end{array}$ & $\begin{array}{l}\text { Ebrahim ve ark., } \\
2015\end{array}$ \\
\hline Tanik asit & HT & $\begin{array}{l}\text { Etlik piliç } \\
\quad(1-12 \\
\text { gün) }\end{array}$ & $0.75-1.5$ & $\begin{array}{l}\text { Civcivlerin dışkı içeriğindeki } \\
\text { Salmonella typhimurium sayısına ya } \\
\text { da dışkı Salmonella pozitif kültürüne } \\
\text { etkisi yok }\end{array}$ & $\begin{array}{l}\text { Kubena ve ark., } \\
2001\end{array}$ \\
\hline Tanik asit & HT & Etlik piliç & $2.5-3.0$ & 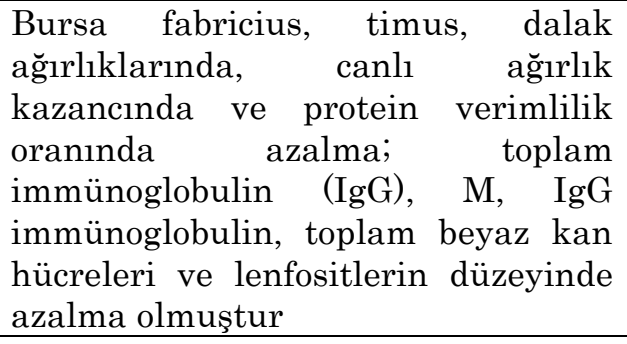 & Marzo ve ark., 1990 \\
\hline $\begin{array}{c}\text { Tatlı } \\
\text { kestane }\end{array}$ & $\mathrm{HT}$ & $\begin{array}{l}\text { Etlik piliç } \\
\quad(0-42 \\
\text { gün) }\end{array}$ & $\begin{array}{c}0.025,0.05 \\
0.1\end{array}$ & $\begin{array}{l}\text { \% } 0.025 \text { ve } \% 0.05 \text { 'lik düzeylerin } \\
\text { büyüme ve yemden yararlanma } \\
\text { üzerine bir etkisi yok; \%0.1'lik } \\
\text { düzeyin karkas kalitesi üzerinde } \\
\text { etkisi yok; İnce bağırsakta E. coli ve } \\
\text { koliform bakterilerde } \\
\text { olmuştur }\end{array}$ & $\begin{array}{c}\text { Jamroz ve ark., } \\
(2009)\end{array}$ \\
\hline $\begin{array}{c}\text { Tatlı } \\
\text { kestane }\end{array}$ & HT & $\begin{array}{l}\text { Etlik piliç } \\
(21-23 \\
\text { gün) }\end{array}$ & $\begin{array}{l}0.07,0.2 \\
0.05,0.15\end{array}$ & $\begin{array}{l}\text { Büyüme performansına, organik } \\
\text { madde, ham protein, Ca ve P } \\
\text { kullanımı üzerinde herhangi bir } \\
\text { etkisi yok; dışkı kuru madde } \\
\text { içeriğinde artış olmuştur }\end{array}$ & $\begin{array}{c}\text { Rezar ve Salobir, } \\
2014\end{array}$ \\
\hline Mimosa & $\mathrm{KT}$ & $\begin{array}{l}\text { Etlik piliç } \\
(21-23 \\
\text { gün) }\end{array}$ & $\begin{array}{l}0.5,1.5 \\
2.0,2.5\end{array}$ & $\begin{array}{l}\text { Yem tüketimi ve vücut ağırlık } \\
\text { kazancında azalma; yemden } \\
\text { yararlanmada \%1,5'dan daha düşük } \\
\text { bir iyileşme; ileumda enerji, protein } \\
\text { veramino asitlerin } \\
\text { sindirilebilirliğinderalma; } \\
\text { pankreatik ve jejunal enzimlerin } \\
\text { aktivitelerine etkisi olmamıştır }\end{array}$ & Iji ve ark., 2004 \\
\hline $\begin{array}{l}\text { Üzüm } \\
\text { ezmesi }\end{array}$ & $\begin{array}{l}\text { KT ve } \\
\text { diğer } \\
\text { fenolikl } \\
\text { er }\end{array}$ & $\begin{array}{l}\text { Etlik piliç } \\
\quad(1-21 \\
\text { gün) }\end{array}$ & 5,10 & $\begin{array}{l}\text { Büyüme performansı üzerine etkisi } \\
\text { yok; but etinin PUFA içeriği ve } \\
\text { oksidaditif stabilitesini artırmıştır }\end{array}$ & $\begin{array}{l}\text { Chamorro ve ark., } \\
2015\end{array}$ \\
\hline
\end{tabular}

HT: Hidrolize tanen; KT:Kondense tanen; PUFA: Çoklu doymamış yağ asitleri

Ağı yoluyla verilen çok düşük miktardaki tanik asitin akut toksit etkisi vardır. LD50 dozu (popülasyonun yarısını öldüren) fare, rat ve tavşanlar için 2.25 ile 6 g/kg vücut ağırlığı arasındadır (Singleton ve Kratzer, 1969). Karma yeme \%0.5 tanik asit ilavesi civcivlerde 
büyümenin gerilemesine ve $\% 5$ düzeyindeki tanik asit ise ölüme neden olmuştur (Salunkhe ve ark, 1989).

Tanenlerin toksisitesi, astrenjan etkiye (inatçı kabızlık) ilave olarak irritan ve hemoliz yapıcı özellik gösteren galik asit, pirogallol gibi hidroliz ürünlerinden kaynaklanmaktadır (Şener ve Yıldırım, 2000).

Fenolik bileşikler iyi bir hidrojen vericisi olmalarından dolayı antioksidan özelliğe sahiptirler (Dillon, 1994). Fenolik bileşiklerden biri olan tanen serbest radikal kabul edicisi gibi davranarak henüz başlangıç aşamasında oksidasyon işlemine engel olur (Mayes, 1993). Tanenlerin mutajenlerin sebep olduğu zararlı etkiyi azalttığı (Chung ve ark., 1998), DNA hasarlarına karşı koruyucu etki gösterdiği düşünülmektedir (Aydın ve Üstün, 2007).

Tanenlerin metal iyonları ile bileşik oluşturmaları sonucunda (daha toksik) antibakteriyel özellik kazandıkları sanılmaktadır (Kaya ve Yalçın, 1999). Demir ile kompleks oluşturan tannik asit, biyofilm oluşturan bakteriler de dahil birçok mikroorganizmanın gelişimini engellemektedir (Hatano ve ark., 2005; Aydın ve Üstün, 2007). Kondense tanenin, gram negatif bakterilere göre gram pozitif bakterilerin gelişimini engellemede çok daha etkili olduğu belirtilmiştir (Bae ve ark., 1993; Jones ve ark., 1994). KT içeren yemlerin tüketimiyle bağırsaklardaki parazitlerinin sayısının azalabileceği belirtilmiştir (Min ve Hart, 2003).

Yüksek tanen içeren yemlerle beslemenin sentetik antioksidan butilen hidroksi toluen'e (BHT) göre piliç etinde oksidatif bozulmaya karşı daha uzun süreli bir koruma sağladığı belirtilmiştir (Naveena ve ark., 2008).

\section{Yemlerdeki Tanen Miktarını Azaltan Uygulamalar}

Kurutma, ıslatma, öğütme, peletleme ve ısıl işlem gibi uygulamalar yem hammaddelerindeki tanen'in etkisini azalmaktadır (Atteh, 2002). Güneşte kurutma (Makkar ve Singh, 1991) ve kurutulmuş halde bekletme ile yemlerin tanen içerikleri zamanla azalmakta (Makkar ve Singh, 1993), islatılma sonucunda ise yemdeki kondense tanen suyla birlikte uzaklaşmaktadır (Wina ve ark., 2005). Etlik piliçlerin beslenmesinde kullanılan mango çekirdek küspesinin tanen içeriğinin kaynatmanın etkisi ile \%75 kadar düştüğü görülmüştür (Diarra ve Usman, 2008). Isıl işlem uygulaması sonucunda ise fasulyenin tanen içeriğinde \%55 ile \%71 kadar bir azalma olmuştur (Ogundipe ve ark., 2008; Ferruzzi ve ark., 2009).

Çeşitli funguslarla fermantasyona uğratılmasıyla yemlerdeki KT parçalanarak daha zararsız küçük moleküllere dönüştürülmektedir (Gamble ve ark., 1996). Üre, kül, kalsiyum hidroksit ve sodyum hidroksit gibi alkalilerle muamele sonucunda yemlerdeki tanen oksitlenerek quinine dönüştügünden KT miktarında önemli miktarda bir azalma meydana gelmektedir (Rojas ve ark., 2002; Makkar, 2003). Ancak alkalilerle muamelede yemlerin besleme değerini olumsuz yönde etkilemektedir (Alain ve ark., 2005; Vitti ve ark., 2005). Bu olumsuzluğu gidermek amaciyla kullanılan polyethylene glycol (PEG) tanen ile kompleks oluşturarak onun proteinle birleşmesi önlenmeye çalışılmaktadır (Silanikove ve ark., 2001).

\section{SONUÇ ve ÖNERİLER}

Kanatlı kümes hayvanlarının beslenmesinde kullanılan yem hammaddeleri değişik oranlarda tanen içermektedir. Tanenler, kanatlı hayvanların iştahına, tükürük salgılamasına, yem tüketimine, yemden yararlanmasina, et ve yumurta verimine, besinlerin sindirim ve emilimine, ayak problemlerine, çeşitli vücut dokularında patolojik değişimlerin meydana gelmesine kadar birçok aşamada etkili olmaktadır.

Yemlerin yapısında bulunan tanen miktarı \%0 ile \%5.7 arasında değişmektedir. \%1 tanen içeren yemlerle beslenen tavuklarin yumurta verimi olumsuz etkilememiş, \%1'den daha fazla tanen bulunması civciv düzeyindeki kanatlı hayvanların gelişmesini engellemiştir. \%2 düzeyindeki tanen ise yumurta veriminin düşmesine neden olmuştur. $\% 2-4$ arasındaki tanen içeren yemlerin tavukların yumurta verimini düşürdüğü görülmüştür. Yemlerdeki, \%5 düzeyinde tanen ise kanatlı hayvanlarda yüksek ölümlerin meydana gelmesine neden olmuştur.

Kanatlı kümes hayvanlarının beslenmesinde tanen içeriği çok yüksek olan yem hammaddelerinin (sorgum vb.) kullanılması zorunlu olduğu durumlarda bunların önceden hiç olmazsa ısıl işleme tabi tutulması, yemlerin protein, demir ve kalsiyum içeriklerinin artırtılması tanenin olumsuz etkilerinin minimize edilmesini sağlayacaktır. Tanenlerin olumsuz etkilerinin yanında faydalı etkilerinin de olduğu unutulmamalıdır. Birçok ilacın yasaklandığı bir yüzyılda, tanenlerin kanatlı hayvan beslemede daha önemli hale geleceği düşünülmektedir.

\section{KAYNAKLAR}

Ağma Okur A 2010. Etlik piliçlerde yemlere aromatik yağlar ve vitamin $\mathrm{E}$ ilavesinin bağırsak mikrobiyolojisi ve oksidatif stabilite üzerine etkileri. Namık Kemal Üniversitesi Fen Bilimleri Enstitüsü, Doktora Tezi, $99 \mathrm{~s}$.

Akar F, Kaya S, Filazi A, Yarsan E 1994. Yem ve yem ham maddelerinde bulunan bazı doğal olumsuzluk faktörleri: 1. Tanen ve siyanür düzeyleri. Ankara Üniversitesi Veteriner Fakültesi Dergisi, 41 (1): 119-131.

Akiyama H, Fujii K, Yamasaki O, Oono T, Iwatsuki K 2001. Antibacterial action of several tannins against staphylococcus aureus. Journal of Antimicrobial Chemother, 48(4): 487-491. 
Aktaş B, Akkan S 2011. Sığır besi yemine ilave edilen meşe palamudu taneninin rumen fermantasyonuna etkilerinin rumen simulasyon tekniği (Rusitek) ile saptanması. Ege Üniversitesi Ziraat Fakültesi Dergisi, 48(3): 249-254.

Alain MR, Kabir Akma, Amin MR, McNeill DM 2005. The effect of calcium hydroxide treatment oil the nutritive and feeding value of Albiza procera for growing goats. Animal Feed Science and Technology, 122(3): 134-148.

Arigator V, Samman S 1994 Intestinal nutrient interactions and significance. Journal of Clinical Nutrition, 48(1):198-204.

Ashok PK, Upadhyaya K 2012. Tannins are astringent. Journal of Pharmacognosy and Phytochemistry. IC Journal No: 8192, 1(3): 45-50.

Atteh JO 2002. Principles and practice of livestock feed manufacturing. Aldek Printers, Ilorin, Nigeria, 10$30 \mathrm{~s}$.

Aydın SA, Üstün F 2007. Tanenler I kimyasal yapıları, farmakolojik etkileri, analiz yöntemleri. İstanbul Üniversitesi Veteriner Fakültesi Dergisi, 33(1): 2131.

Bae HD, Mcallister TA, Yanke J, Cheng KJ, Muir AD 1993. Effects of condensed tannins on endoglucanase activity and filter paper digestion by Fibrobacter succinogenes S85. Applied and Environmental Microbiology, 59(7):2132-2138.

Bele AA, Varsha JM, Nikam SR, Vilasrao JK 2009. Antibacterial potential of herbal formulation. Research Journal of Microbiology, 4 (4): 164-167.

Chamorro S, Viveros A, Rebolé A, Rica BD, Arija I, Brenes A 2015. Influence of dietary enzyme addition on polyphenol utilization and meat lipid oxidation of chicks fed grape pomace. Food Research International,73 (1): 197-203.

Chung KT, Wei CI, Johnson MG 1998. Are tanens a double-edged sword in biology and health? Trends in Food Science and Technology, 9(4):168-175.

Diarra SS, Usman BA 2008. Growth performance and some blood variables of broiler chickens fed raw or boiled mango kernel meal. International Journal of Poultry Science, 7(4): 315-318.

Dillon, YM 1994. Natural antimicrobial systems and food preservation. CAB International, Oxon, 167$179 \mathrm{~s}$.

Doka O, Bicanic DD, Dicko MH, Slingerland MA 2004. Photoacoustic approach to direct determination of the total phenolic content in red sorghum flours. Journal of Agricultural and Food Chemistry, 52 (8): 2133-2136.

Ebadi MR, Pourreza J, Jamalian J, Edriss MA, Samie AH, Mirhadi SA 2005. Amino acid content and availability in low, medium and high tannin sorghum grain for poultry. International Journal of Poultry Science, 4 (1): 27-31.

Ebrahim R, Liang JB, Jahromi MF, Shokryazdan P, Ebrahimi M, Chen WL 2015. Effects of tannic acid on performance and fatty acid composition of breast muscle in broiler chickens under heat stress. Italian Journal of Animal Science, 14 (4):572-577.

Edwin-Jarald E 2007. Pharmacognosy and Phytochemistry. 1st Edn., Lavoisier, New York, 377 S.

Ferruzzi G, Pistoia A, Balestri G, Casarosa L, Poli P 2009. Effect of different processing methods on the nutritional characteristics and tannin content of fababean seed (Vicia faba minor), Italian Journal of Animal Science, 8(2): 298-300.

Flores MP, Castonin JIR, McNab JM 1994. Effect of tannins on starch digestibility and TME of tritriclate and semi purified starches from tritriclate and field beans. British Poultry Science, 35(2):281-286.

Funatogawa K, Hayashi S, Shimomura H, Yoshida T, Hatano T, Ito H, Hirai Y 2004. Antibacterial activity of hydrolyzable tannins derived from medicinal plants against Helicobacter pylori. Microbiology and Immunology, 48(4):251-261.

Gamble GR, Akin DE, Makkar HPS, Becker K 1996. Biological degradation of tannin in Sericea lespedeza by the white fungi Ceriporiopsis subvermispora and Cyatlms sfercoreus analysed by solid state 13C NMR spectroscopy. Applied and Environmental Microbiology, 62(10): 3600-3604.

Gawel R. 1998. Red wine astringency: a review. Australian Journal of Grape and Wine Research, $4(2): 74-95$.

Gnanamani A, Sekaran G, Babu M 2001. Removal of tannin from cross-linked and open chain polymeric tannin substrates using heme peroxidases of Phanerochaete chrysosporium. Bioprocess and Biosystems Engineering, 24(4): 211-217.

Goel G, Puniya AK, Singh K 2005. Interaction of gut microflora with tannins in feeds. Naturwissenschaften, 92(11): 497-503.

Goun EA, Petrichenko VM, Solodnikov SU, Suhinina TV, Kline MA, Cunningham G, Nguyen C, Miles H 2002. Miles, "Anticancer and antithrombin activity of Russian plants", Journal of Ethnopharm, 81(3): 337-342.

Gualtieri M, Rappaccini S 1990. Sorghum grain in poultry feeding. World's Poultry Science Journal, 46(3): 246-254.

Hagerman AE 2002. The tannin handbook. Miami University Oxford, $\mathrm{OH}$ 45056, http://chemistry.muohio.edu/hagerman (Erişim tarihi:01.11.2017).

Hassan IAG, Elzubeir EA, El Tinay AH 2003. Growth and apparent absorption of minerals in broiler chickens fed diets with low and high tannin contents. Tropical Animal Health and Production, 35(2):189-196.

Hassanpour S, Sadaghian M, Maheri Sis N, Eshratkhah B, Chaichi Semsari M 2011. Effect of condensed tannin on controlling faecal protein 
excretion in nematode-infected sheep: in vivo study. Journal of American Science, 7(5): 896- 900.

Hatano T, Kusudo M, Inada K, Ogawa T, Shiota, S, Tsuchiya T, Yoshida T 2005. Effects of tannins and related polyphenols on methicillin-resistant Staphylococcus aureus. Phytochemistry, 66(17): 2047-2055.

Iji PA, Khumalo K, Slippers S, Gous RM 2004. Intestinal function and body growth of broiler chickens on maize-based diets supplemented with mimosa tannins and a microbial enzyme. Journal of Science Food and Agriculture, 84 (12): 1451-1458.

Jamroz D, Wiliczkiewicz A, Skorupinska J, Orda J, Kuryszko J, Tschirch H 2009. Effect of sweet chestnut tannin (SCT) on the performance, microbial status of intestine and histological characteristics of intestine wall in chickens. British Poultry Science, 50(6):687-699.

Jones GA, Mcallister TA, Muir AD, Cheng KJ 1994. Effects of sainfoin (Onobrychis viciifolia Scop.) condensed tannins on growth and proteolysis by four strains of ruminal bacteria. Applied and Environmental Microbiology, 60(4): 1374-1378.

Katie E, Ferre LL, Thorindton, RW 2006. Squirrels: The animal answer guide Baltimore. Johns Hopkins University press, 91 s. ISBN 0-8018-84020.

Kaur G, Hamid H, Ali A, Alam MS, Athar M 2004. Antiinflammatory evaluation of alcoholic extract of galls of Quercus infectoria. Journal of Ethnopharm, 90(2-3): 285-292.

Kaya İ, Yalçın S 1999. Baklagil tane yemleri ve ruminant rasyonlarında kullanımı. Lalahan Hayvancılık Araştırma Enstitüsü Dergisi, 39(1): 101-114.

Kaya S, Yavuz H 1993. Yem ve yem hammaddelerinde bulunan olumsuzluk faktörleri ve hayvanlara yönelik etkileri. 1: Organik nitelikli olumsuzluk faktörleri. Ankara Veteriner Fakültesi Dergisi, 40 (4): 586-614.

Khanbabaee K, Ree T 2001. Tannins: Classification and definition. Natural Product Reports,18(6): 641649.

Kolodziej H, Kiderlen AF 2005. Antileishmanial activity and immune modulatory effects of tannins and related compounds on Leishmania parasitised RAW 264.7 cells. Phytochemistry, 66(17): 20562071.

Kubena LF, Byrd JA, Young CR, Corrier DE 2001. Effects of tannic acid on cecal volatile fatty acids and susceptibility to Salmonella typhimurium colonization in broiler chicks. Poultry Science, 80(9): 1293-1298.

Kuloğlu R 2007. Tanik asidin rumen bakterilerinin bazı fibrolitik enzimlerine etkisi. Kahramanmaraş Sütçü İmam Üniversitesi, Fen Bilimleri Enstitüsü, Zootekni ABD, Yüksek Lisans Tezi, 37 s.
Kumar V, Ecangovan AV, Mandal AB 2005. Utilization of reconstituted high tannin sorghum in the diet of broiler chickens. Asian Australasian Journal of Animal Science, 18(4): 538-544.

Kumar V, Elangovan AV, Mandal AB, Tyagi PK, Bhanja SK, Dash BB 2007. Effects of feeding raw or reconstituted high tannin red sorghum on nutrient utilisation and certain welfare parameters of broiler chickens. British Poultry Science, 48 (2): 198-20.

Lewis NG, Yamamoto E 1989. Tannins: Their place in plant metabolism. In: chemistry and significance of condensed tannins. Hemingway RW and Karchesy JJ (eds). Plennum Press, New York, 22-46 s.

Lin MK, Chang BY, Liao JT, Lin NS, Hsu YH 2004. Arg-16 and Arg-21 in the N-terminal region of the triple-gene-block protein 1 of Bamboo mosaic virus are essential for virus movement. Journal of General Virology, 85(Pt 1): 251-259.

Longstaff MA, McNab JM 1991. The inhibitory effects of hull polysaccharides and tannins of field beans (Vicia faba L.) on the digestion of amino acids, starch and lipid and on digestive enzyme activities in young chicks. British Journal of Nutrition, 65(2): 199-216.

Mahmood S, Khan MA, Sarwar M, Nisa M 2006. Chemical treatments to reduce antinutritional factors in salseed (Shorea robusta) meal: Effect on nutrient digestibility in colostomized hens and intact broilers. Poultry Science, 85(12): 2207-2215.

Makkar HPS, Singh B 1991. Distribution of condensed tannins in various fibre fractions in young and mature leaves of some oak species. Animal Feed Science and Technology, 32(4):253-260.

Makkar HPS, Singh B 1993. Effect of dosage and urea addition on detannification and in sacco dry matter digestibility of mature oak leaves. Animal Feed Science and Technology, 41(3):247-259.

Makkar HPS 2003. Effects and fate of tannins in ruminant animals, adaptation to tannins and strategies to overcome detrimental effects of feeding tannin rich feeds. Small Ruminant Research, 49(3): 241-256.

Marquardt RR 1989. Dietary effects of tannins, vicine and convicine. In: Huisman, J., van der Poel, A.F.B. and Liener, I.E. (Eds.), Recent advances research. antinutritonal factors in legume seeds, Proc. 1st Int. Workshop, Wageningen, The Netherlands, 141$155 \mathrm{~s}$.

Martin JS, Michael MM 1983. Tannin assays in ecological studies precipitation of ribulose-1,5bisphosphate carboxylase/oxygenaseby tannic acid, quebracho, and oak foliage extracts, Journal of Chemical Ecology, 9(2): 285-294.

Martin-Tanguy J, Guillaume J, Kossa A 1977. Condensed tannins in horse bean wed: chemical structure and apparent effect on poultry. Journal of the Science of Food and Agriculture, 28(8): 757-766. 
Marzo F, Tosar A, Santidrian S 1990. Effect of tannic acid on the immune response of growing chickens. Journal of Animal Science, 68 (10): 3306-3312.

Mayes PA 1993. Lipitlerin fizyolojik önemi. Harper'ın biyokimyası, Ed. R. Murray, P.A. Mayes, D.K. Granner, V.W. Rodwell, Çeviri: Prof. Dr. Gülriz Menteş, Prof. Dr. Biltan Ersöz, Barış Kitabevi; ISBN: 975-95 331-1-1, 171- 185 s.

McCune ML, Johns T 2002. Antioxidant activity in medicinal plants associated with the symptomps of diabetus mellitus used by the indigenous peoples of the North American boreal forest, Journal of Ethnopharmacology, 82(2-3): 197-205.

Medugu CI, Saleh B, Igwebuike JU, Ndirmbita RL 2012. Strategies to improve the utilization of tannin-rich feed materials by poultry. International Journal of Poultry Science, 11(6): 417-427.

Min BR, Barry TN, Attwood GT, McNabb WC 2013. The effect of condensed tannins on the nutrition and health of ruminants fed fresh temperate forages: A review. Animal Feed Science and Technology, 106(3): 3-19.

Musharaf NA, Latshaw JD 1991. Effect of tannin extraction on the feeding value of grain sorghum in broiler starter diets. Sudan Journal of Animal Production, 4(1): 53-64.

Naveena BM, Sen AR, Vaithiyanathan S, Babji Y, Kondaiah N 2008. Comparative efficacy of pomegranate juice, pomegranate rind powder and BHT in cooked chicken patties. Meat Science, 80(4):1304-308.

Nyachoti CM, Atkinson JL, Leeson S 1997. Sorghum tannins:A review. World's Poultry Science Journal, 53(1):5-21.

Ogundipe, SO, Damang PJ, Dafwang II, Abu EA, 2008. Biochemical evaluation of raw and cooked African locust bean seeds (Parkia spp) for poultry feeding. Proceedings of the 13th Annual Conference of the Animal Science Association of Nigeria (ASAN), 15th-19th Sept., 2008. ABU, Zaria, Nigeria, 586$589 \mathrm{~s}$.

Olomu JM 1995. Monogastric Animal Nutrition: Principles and practice. A Jackem Publication Benin City (1st Edn.), 285 s.

Ortiz LT, Alzueta C, Trevino J, Castano M 1994. Effects of faba bean tannins on the growth and histological structure of the intestinal tract and liver of chicks and rats. British Poultry Science, 35(5): 743-754.

Reed JD 1995. Nutritional toxicology of tannins and related polyphenols in forage legumes. Journal of Animal Science, 73(5): 1516-1528.

Reyes Sanchez E, Cortez Cuevas A, Morales Barrera E, Avila Gonzalez E 2000. DL-methionine addition in high tannin sorghum grain diets for broilers. Tecnica Pecuaria on Mexico, 38(1):1-8.

Rezar V, Salobir J 2014. Effects of tannin-rich sweet chestnut (Castanea sativa mill.) wood extract supplementation on nutrient utilisation and excreta dry matter content in broiler chickens. European Poultry Science;78(1):1-10.

Rojas JBU, Verreth JAJ, Van Weer JH, Huisman EA 2002. Effect of different chemical treatments on the nutritional and antinutritional properties of coffee pulp. Animal Feed Science and Technology, 99(1):195-204.

Salunkhe, DK, Chavan JK, Kadam SS 1989. Dietary tannins: Consequenses and Remedies. CRC Press, Boca Raton, Florida, $208 \mathrm{~s}$.

Schofield P, Mbugua DM, Pell AN 2001. Analysis of condensed tannins: a Review. Animal Feed Science and Tecnology, 91(1): 21-40.

Selle PH, Cadogan DJ, Li X, Bryden WL 2010. Review; Implications of sorghum in broiler chicken nutrition. Animal Feed Science and Technology, $156(3-4): 57-74$.

Silanikove N, Nitsan Z, Perevolotsky A 1994. The effect of daily suplementation of polyetyhelene glycol on intake and digestion of tannin-containing leaves (Ceratonia siliqua) by sheep. Journal of Agricultural and Food Chemistry, 42(12): 28442847.

Silanikove N, Perevolotsky A, Provenza FD 2001. Use of tannin-binding chemicals to assay for tannins and their negative postingestive effects in ruminants. Animal Feed Science and Technology, 91(1-2): 69-81.

Singleton VL, Kratzer FH 1969. Toxicity and related physiological activity of phenolic substances of plant origin. Journal of Agriculture Food Chemistry, 17 (3):497-512.

Starčević K, Krstulović L, Brozić D, Maurić M, Stojević Z, Mikulec Ž, Bajić M, Mašek T 2015. Production performance, meat composition and oxidative susceptibility in broiler chicken fed with different phenolic compounds. Journal of the Science of Food and Agriculture, 95(6): 1172-1178.

Şener S, Yıldırım M 2000. Veteriner Toksikoloji. Teknik Yayıncılık, 221-223 s.

Üstün F, Aydın SA 2007. Tanenler. 2. Toksisiteleri, beslenme üzerine etkileri, detannifikasyon. İstanbul Üniversitesi Veteriner Fakültesi Dergisi, 33(1): 33-41.

Vitti, DMSS, Nozella EF, Abdalla AL, Bueno ICS, Silva Filho JC, Costa C, Bueno MS, Longo C, Vieira MEQ, Cabral Filho SLS, Godoy PB, Mueller-Harvey I 2005. The effect of drying and urea treatment on nutritional and anti-nutritional components of browses collected during wet and dry seasons. Animal Feed Science and Technology, 122(1-2): 123133.

Wina E, Tangendjaja B, Susana IWR 2005. Effects of chopping and soaking in water, hydrochloric acidic and calcium hydroxide solutions on the nutritional value of Acacia viilosa for goats. Animal Feed Science and Technology, 122(1-2): 79-92. 
Yalçın S 2013. Yemlerde antinutrisyonel faktörler, yemler ve yem hijyeni ve teknolojisi, genişletilmiş 5. baskı. Ankara Üniversitesi, Veteriner Fakültesi, 261-286 s.

Yavuz H, Akar F, Kerman M, Şanlı Y, Yarsan E, Filazi A 1997. Türkiye'de üretilen veya ithal edilen yem ve yem ham maddelerinin hayvan sağlığ ve verimliliği yönünden önem taşıyan nitrat-nitrit, tannik asit ve siyanür içerikleri üzerine araştırmalar. Etlik Veterinerlik Mikrobiyoloji Dergisi, 9 (1): 57-88.

Yilmaz Y, Toledo RT 2004. Major flavonoids in grape seeds and skins: Antioxidant capacity of catechin, epicatechin and gallic acid.. Journal Agriculture and Food Chemistry, 52 (2): 255-260.

Živković J, Mujić I, Zeković Z, Nikolić G, Vidović S, Mujić A 2009. Extraction and analysis of condensed tannins in Castanea sativa Mill. Journal of Central European Agriculture, 10 (3): 283-288. 